\title{
Some Little-Known Designs by Louis-Pierre Baltard and Jean-Baptiste Rondelet for the Transformation of the Church of the Madeleine into a Temple of Glory
}

\author{
David W. Booth
}

Volume 16, numéro 2, 1989

Études sur l'architecture et son environnement

Studies on Architecture and its Environment

URI : https://id.erudit.org/iderudit/1073145ar

DOI : https://doi.org/10.7202/1073145ar

Aller au sommaire du numéro

\section{Éditeur(s)}

UAAC-AAUC (University Art Association of Canada | Association d'art des universités du Canada)

ISSN

0315-9906 (imprimé)

1918-4778 (numérique)

Découvrir la revue

Citer cet article

Booth, D. W. (1989). Some Little-Known Designs by Louis-Pierre Baltard and Jean-Baptiste Rondelet for the Transformation of the Church of the Madeleine into a Temple of Glory. RACAR : Revue d'art canadienne / Canadian Art Review, 16(2), 147-154. https://doi.org/10.7202/1073145ar

\section{Résumé de l'article}

Napoléon au sommet de sa gloire et de sa puissance ordonna le 2 décembre 1806 par décret, la tenue d'un concours pour la transformation de l'église de la Madeleine en un temple civique dédié à la Grande Armée. Evénement artistique extraordinaire de l'Empire auquel participèrent tous les architectes en vue et qui demeure mal connu faute de documents. Pour ajouter à la difficulté de connaître toute l'histoire de ce concours, les candidats, qui furent jugés dans l'anonymat, eurent le droit de récupérer leurs travaux après le concours. L'issue du concours fut encore compliquée par le rejet du $1^{\mathrm{er}}$ prix accordé à Claude Etienne de Beaumont; l'Empereur préféra le projet de Pierre Vignon qui gagna le $2^{\mathrm{e}}$ prix, car il fut plus conforme à sa conception du « beau antique ".

Le CCA possède un album élaboré par Louis-Pierre Baltard (1764-1846) et par Jean-Baptiste Rondelet (1743-1829) qui nous présente quelques renseignements nouveaux sur certains aspects du concours. Les deux architectes, arrivés au cinquième rang, furent autorisés à soumettre à nouveau leur projet à l'Empereur, vraisemblablement entre le 4 avril 1807, date de la publication des résultats du concours, et le 9 juin 1807, jour où le choix de Napoléon fut officiellement connu, ou peu de temps après. Rien ne prouve que Napoléon ait vu ce projet hors concours qui a pourtant le mérite de répondre parfaitement aux exigences édictées dans le programme. Cinq rendus spectaculaires nous montrent un temple à portique, de forme longitudinale, entouré de colonnes et terminé par une abside en hémicycle; l'édifice est bien adapté aux cérémonies solennelles, civiques, et militaires pour lesquelles l'Empereur voulait un sanctuaire commératif. Ces dessins, qu'on peut attribuer à Louis Pierre Baltard, sont très révélatrices de ses talents et prouvent qu'il jouissait d'une assez grande réputation bien avant la réalisation en 1815 de sa première oeuvre connue, la chapelle du Prison de Sainte-Pélagie. Selon l'inscription de la page frontispice, le temple romain de Mars Ultor fut choisi par Baltard et Rondelet comme prototype de leur projet de transformer l'église de la Madeleine. Cette suggestion faite à un moment où Napoléon aimait à se comparer à Alexandre le Grand et prisait l'antiquité grecque, a-t-elle nui au sort du projet de Baltard et Rondelet ? Quoi qu'il en soit, l'album de Baltard et de Rondelet constitue un des derniers documents de l'histoire tumultueuse de l'église de la Madeleine et vient s'ajouter aux témoignages sur l'évolution du goût dans la domaine de l'architecture pendant l'époque qu'on appelle néo-classique.
Tous droits réservés (C UAAC-AAUC (University Art Association of Canada | Association d'art des universités du Canada), 1989
Ce document est protégé par la loi sur le droit d'auteur. L’utilisation des services d'Érudit (y compris la reproduction) est assujettie à sa politique d'utilisation que vous pouvez consulter en ligne.

https://apropos.erudit.org/fr/usagers/politique-dutilisation/ 


\title{
Some Little-Known Designs by Louis-Pierre Baltard and Jean-Baptiste Rondelet for the Transformation of the Church of the Madeleine into a Temple of Glory
}

\author{
DAVID W. BOOTH \\ Centre Canadien d'Architecture/Canadian Centre for Architecture
}

RESUME

Napoléon au sommet de sa gloire et dc sa puissance ordonna le 2 décembre 1806 par décret, la tenue d'un concours pour la transformation de l'église de la Madelcine en un temple civique dédié à la Grande Armée. Evénement artistique extraordinaire de l'Empire auquel participèrent tous les architectes en vue et qui demeure mal connu faute de documents. Pour ajouter à la difficulté de connaître toute l'histoire de ce concours, les candidats, qui furent jugés dans l'anonymat, eurent le droit de récupérer leurs travaux après le concours. I'issue du concours fut encore compliquée par le rejet du ler $^{\text {er }}$ prix accordé à Claude Etienne de Beaumont; l'Empereur préfèra le projet de Pierre Vignon qui gagna le $2^{\mathrm{e}}$ prix, car il fut plus conforme à sa conception du "beau antique".

Le cca possède un album élaboré par Louis-Pierre Baltard (1764-1846) et par Jean-Baptiste Rondelet (1743-1829) qui nous présente quelques renseignements nouveaux sur certains aspects du concours. Les deux architcctes, arrivés au cinquièmc rang, furent autorisés à soumettre à nouveau leur projet à l'Empereur, vraisemblablement entre le 4 avril 1807, date de la publication des résultats du concours, et le 9 juin 1807 , jour où le choix de Napoléon fut officiellement connu, ou peu de tcmps après. Rien ne prouve que Napoléon ait vu ce projet hors concours qui a pourtant le mérite de répondre parfaitement aux exigences édictées dans le programme. Cinq rendus spectaculaires nous montrent un temple à portiquc, de forme longitudinale, cntouré de colonnes et terminé par une abside en hémicycle; l'édifice est bien adapté aux cérémonies solennelles, civiques, et militaires pour lesquelles l'Empereur voulait un sanctuaire commératif. Ces dessins, qu'on pcut attribuer à Louis Pierre Baltard, sont très révélatrices de ses talents et prouvent qu'il jouissait d'une assez grande réputation bien avant la réalisation en 1815 de sa première ocuvre connue, la chapelle du Prison de SaintePélagie. Selon l'inscription de la page frontispice, le temple romain de Mars L'ltor fut choisi par Baltard et Rondelct comme prototype de leur projet de transformer l'église de la Madeleine. Cettc suggestion faite à un moment où Napoléon aimait à se comparer à Alcxandre le Grand et prisait l'antiquité grecque, a-t-elle nui au sort du projet de Baltard et Rondelct? Quoi qu'il en soit, l'album de Baltard et de Rondelet constitue un des derniers documents de l'histoire tumultueuse de l'église de la Madclcine et vient s'ajouter aux témoignages sur l'évolution du goût dans la domaine de l'architecture pendant l'époque qu'on appelle néo-classique.
The church of the Madeleine in Paris has a long and fitful history. ${ }^{1}$ From the first decision to

1 I would like to thank Nicholas Olsberg and Myra Nan Rosenfeld for their helpful suggestions in preparing this article. For the history of the Madeleine in the eighteenth and ninetecnth centuries, see L. Gruel, La Madeleine depuis son établissement à la Ville Evêque (Paris, 1910); G. Vauthier, replace the old building to the completion of the new one, nearly 100 years passed by. Throughout

"Pierre Vignon et l'église de la Madeleine," Bulletin de la Société de l'Histoire de l'Art (1910), 380-422; A. Krićger, La Madeleine (Paris, 1937), 251-87; M.-L. Biver, Le Paris de Napoléon (Paris, 1963), 232-49; and P.-F.-L. Fontainc, Journal, 1799-1853, 2 vols. (Paris, 1987). 
that period, the project, occupying a site critical to the absorption of the northwestern suburbs into the formal fabric of the city, accurately reflected both changing stylistic sensibilities and the different aspirations for a metropolitan monument on the part of its successive designers and sponsors. Through the history of the Madeleine, the historian can watch, in the unfolding of a single structure, the changing architectural tastes of the entire neo-classical era, as each new proposal redefines the sense of what and how the contemporary architect should draw from ancient models. At the same time, each new idea, for what a monument of this prominence might be, mirrors the mercurial official ethos of the time, from a projected national church in the ancien régime to a checkerboard of civic uses after the Revolutionlegislative assemblies, tribunals, festival halls, and libraries.

In 1988, the CCA acquired an album of designs related to the last and perhaps the most extravagant of these efforts to secularize the church of the Madeleine. ${ }^{2}$ As will be shown, this albumexecuted by Louis-Pierre Baltard (1764-1846) and Jean-Baptiste Rondelet (1743-1829) — was produced in connection with a competition held by Napoleon in 1806-1807 for the completion of the eighteenth-century structure begun by Pierre Contant d'Ivry (1689-1777). The church was subsequently continued, but left unfinished by Guillaume-Martin Couture le Jeune (1737-99). The purpose of Napoleon's competition was to turn Contant's and Couture's church of the Madeleine into a veritable temple, on the classical model, that would serve as the Emperor's tribute to the military victories of his Grande Armée. The present building, begun in 1809 as a Temple of Glory according to the designs of Pierre Vignon (1763-1828) and completed in 1842 by Jean Jacques Huvé (1783-1852) as a church, derives from this competition.

The ccA's album consists of two green parchment covers, bound with the single leaf of an introductory address on folios $3 \mathrm{r}$ and $3 \mathrm{v}$ and five sheets of drawings interspersed with blank folios. The front parchment cover (Fig. 163) carries the title

2 This album was acquired by the cca from Hazlitt, Gooden, and Fox Ltd., London: see their catalogue, Design: Drau'ings for Architecture, Costume, and the Decorative Arts, from 1570 (London, 1989), No. 31, 121-26. The album was also exhibited at the CCA, 20 September to 19 November 1989 , and has been published by Barry Bergdoll in "Le Panthéon/Sainte-Geneviève au xıx" siècle. La monumentalité à l'éprcuve des révolutions idéologiques (1806-1885)," in Le Panthéon: Symbole des révolutions (Paris and Montréal, 1989), 182-85. See 183-84 for illustrations of the ground plan (Fig. 173, here), of the longitudinal elevation (Fig. 172, here), and of the cross-section (Fig. 171, here) of the project and the signatures of both its authors written in black ink:

PROJET de MONUMENT/sur l'emplacement de/L'FGIIISE. DE LA MADEIfIN / par/Rondelet membre du Comité Consultatif des/Batiments de la Couronne et Baltard architecte.

The short introductory address, also signed by Baltard and Rondelet, enunciates the authors' intentions (Figs. 164 and 165): to aim for a simplicity that would render the building both more imposing and less expensive; to devclop a plan that would move them away from traditional church forms and thus give the building a form more consistent with its purpose as a Temple of Glory; and to adopt the Temple of Mars Ultor in the Forum of Augustus in Rome as their model. Protesting that only the Emperor could decide on their degree of success in achieving these goals, the authors further claim that the rigour of their calculations allows them to guarantee their estimate of 2,846,377 francs for the construction of the monument. Also found between the green parchment covers but not bound in, are a 10-page fragment of a printed pamphlet pertaining to the competition (Figs. 166 and 167) and a 44-page manuscript devis, or estimate of costs (Fig. 168), both anonymous. On the verso of the front parchment cover, the album has the book plate of Hippolyte-Alexandre-Gabriel-Walter Destailleur (1822-93), the important French architect, collector of architectural drawings, and bibliophile. ${ }^{3}$

The drawings, all of presentation quality, are carefully delineated in pen and black ink, and expertly rendered with a variety of wash and watercolour. Drawing number one (Fig. 169) shows the elevation of the principal façade, consisting of an antique temple front with three doors

3 More research is needed on the provenance of this album, since a pencil notation, "/4500/Vente Destailleur N." 358" on folio $2 \mathrm{r}$ of the album has not been verified. For Destailleur's life and the various sales of his collections, see E. Berckenhagen, Staatliche Museen, Pressischer Kulturbesitz, Französischen Zeichnungen der Kunstbibliothek Berlin (Berlin, 1970), 5-7; "Hippolyte Destailleur," in Fünf Architekten aus Fünf Jahrhunderten (Berlin, 1976), 114-15; and F. Lugt, Les marques de collections (Amsterdam, 1921), 132-34.

4 This drawing is backed by a lithograph of Minerva, much in the style of the lithographs executed by Baltard showing the sculptural decorations carried out by Jcan-Guillaume Moitte in 1792 for the pediment of the portico of SteGeneviève. For illustrations of those lithographs in the CCA's collection (DR1984:1598 and 1602-1604), see Le Panthéon: symbole des révolutions, 128-29. The preparatory drawing by Baltard in the Cabinet des Dessins of the Musée du Louvre for these lithographs has been published by Thérèse de Puylaroque, "Louis-Pierre Baltard, Peintre et dessinateur (1764-1846)," Bulletin de la Société de l'histoire de l'art français (1976), fig. 9, 338. These lithographs are discussed in an unpublished report by Rosenfeld, 21 June 1984, CcA Prints and Drawings Research Files. 
shown behind. Its entablature bears a dedication that reads: L'EMPEREUR NAPOLEON AUX SOLDATS DE $L A$ GRANDE ARMEE. Surmounting the entablature is a gabled pediment that contains a bas-relief sculpture depicting an allegory of the benefits of military victory.

Drawing number two (Fig. 170), larger in scale than the other drawings and alone in having a border, represents details of the ornament from the left upper corner of the principal façade shown in drawing number one. The draughtsman has painstakingly drawn in a delicately foliated Corinthian capital on an unfluted shaft, and a rich ensemble of cymae, ovoli, astragals, and modillions.

The third drawing (Fig. 171) is a cross-section taken at the end of the nave of the Temple of Glory and shows in detail a view of the apse. The apse itself is covered by a half-dome that is lit from above by an oculus and is supported by a colonnade with a straight entablature. A throne on a raised dais which can be approached by a series of steps is placed in front of the colonnade. To either side, at the end of the barrel-vaulted nave, are winged figures of victory seated on two-tiered bases in the antique style. Against the lateral walls of the nave are standing figures in modern dress. These figures, placed on pedestals, are raised above the main floor level by rows of seats shown in section. A row of freestanding columns and a short flight of steps articulate the exterior walls of the nave.

Drawing number four (Fig. 172) has fold-out flaps at either end and reveals a section taken through the length of the proposed building. It shows that the entrance portico of the Temple of Glory is two columns deep, that the barrel-vaulted nave is articulated at each extremity by a transverse arch supported by piers, and that the apse is crowned by a semi-circular vault, which rests on a colonnade that acts as a screen in front of a double-storeyed ambulatory. This drawing also reveals that the interior of the Temple of Glory is, in fact, lit by four oculi, one in the crown of the semi-circular vault of the apse, and three spaced equally along the crown of the barrel vault over the nave. All the vaults are coffered in an antique manner, and the coffers are decorated with painted panels and medallions. Between the winged figures of victory seated before the piers at the extremities of the nave appear a series of military trophies set in 11 niches that alternate with 12 figures on pedestals along the side walls of the nave. These latter figures, as well as those which appear in the relief in the frieze below the barrel vault, are dressed in modern military uniform.
The last sheet, which we shall call drawing number five (Fig. 173), also has large fold-out flaps and is extensively inscribed with notes, a legend, a brief estimate of costs, and the signatures of Baltard and Rondelet. On this sheet are shown two proposals for the Temple of Glory. One is represented by a large ground plan in the centre. The second project is presented in a ground plan, an elevation of the principal façade, a side elevation, and a cross-section, all drawn in a much smaller scale on the lower portions of the sheet. The large ground plan represents a version of Couture's original scheme, together with the proposed modifications, which can be distinguished by the coloured washes. According to the notes, the yellow wash indicates parts of the existing structure to be demolished; the grey-black wash shows the parts to be conserved; and the red wash designates the parts necessary to be constructed for the new building. Couture's original project consisted of a stretched Greek cross plan with a dome over the crossing, a nearly circular apse, and free-standing columns around the exterior walls of the nave. The proposed new building is to be built according to a longitudinal, basilical plan with a dipteral portico, free-standing columns along the exterior walls of the nave, and a semicircular apse preceded by stair towers that take the form of short transept arms. Represented in the four drawings at the foot of the large plan, the second proposal differs from the first only in that the architects add a series of interconnecting chambers to the ambulatory and place at the entrance of the nave a screen closely imitating a Roman triumphal arch.

In order to fully understand the contents of the album, it is necessary to view them against the historical background of the Madeleine, as well as in the context of the events that immediately preceded the confirmation of Pierre Vignon as architect of the project. The decision to replace the old parish church of La Sainte-Madeleine de la Ville l'Evêque was taken in 1757, when Louis xv announced his intention to build a new church of the same name on the axis of the rue Royale in order to close the view looking north from AngeJacques Gabriel's (1710-82) Place Louis xv (1755-71), now the Place de la Concorde. Plans were drawn up by Pierre Contant d'Ivry and approved by the King on 14 February 1761 . These plans, preserved in the Archives Nationales, ${ }^{5}$ show a church in the form of a Latin cross

\footnotetext{
5 See the exhibition catalogue Soufflot et son temps (Paris, 1980), nos. 281-84, 142-44, illustration of no. 282, 144. Contcmporary engravings of Contant's original project are reproduced in A. Braham, The Architecture of the French Enlightenment (London, 1980), fig. 58, 52.
} 
with an exterior somewhat retardataire in style. Contant's project was heavily criticized, and a revised project, in which the nave was reduced from seven to three bays, was produced. The first stone was laid by Louis xv on 3 April 1764. Under the pressure of continued criticism, Contant made changes to his project until his death in 1777. At this point Guillaume-Martin Couture le Jeune, an architect associated with the construction of Contant's project for the Madeleine, was made architect. Couture submitted a new plan, approved by the Conseil d'Etat on 31 December 1777, calling for the demolition of part of Contant's structure and the erection of a church on a stretched Greek cross plan, with an octastyle temple front, a nearly independent circular apse, and a nave surrounded by a colonnade on the exterior. ${ }^{6}$

Couture's project suffered the same bitter fate as that of his predecessor. First, both his appointment and his proposal incurred the public wrath of Contant's jealous son-in-law and collaborator Dullin, le Fils. Then his difficult temperament brought him into conflict with the Royal Academy of Architecture and Count Charles-Claude d'Angiviller, the Directeur général des bâtiments du roi. This long-delayed work was then interrupted by the onset of the Revolution and came to a complete and official end on 28 January 1793.

During the Revolutionary period, several proposals were made for the transformation and completion of the church of the Madeleine, some drawn up, some merely suggested. In 1791, Pierre Vignon, Jacques-Guillaume Legrand (1743-1807) and Jacques Molinos (1743-1831) submitted plans for converting the Madeleine into the Hall of the National Assembly. ${ }^{7}$ Later, Jean-FrançoisThérèse Chalgrin (1739-1811) suggested it be turned into a hall for celebrating national holidays; and Alexandre-Jean-Baptiste-GuyGisors le Jeune (1762-1835) and Antoine-François Peyre (1739-1823) each provided plans for a national library on the site. ${ }^{8}$ But, by the coup d'état

6 Couture's original plans are also preserved in the Archives Nationales, Paris. See Soufflot et son temps, nos. 292-93, 148. A contemporary engraved plan of Couture's project is reproduced in Braham, French Enlightenment, fig. 59, 53. Further research is needed to determine exactly how much of Contant's church was erected and exactly how much of his church was destroyed.

7 Vauthier, "Pierre Vignon," 383-84; Kriégcr, La Madeleine, 257; L. Hautecoeur, Histoire de l'architecture classique en France (Paris, 1953), v, 115-16, 204. The plans of Legrand and Molinos were submitted to the Conseil du Département de Paris by Armand-Guy Kersaint on 15 December 1791, and published in an engraved form in his Discours sur les monuments publics (Paris, 1792). The cca owns a set of five drawings by Legrand and Molinos for this project, DR 1976:0010-0014

8 Vauthier, "Pierre Vignon," 284; Hautccoeur, Histoire, v, 204. of 9-10 November 1799, no decision had been taken.

Further proposals for the site of the Madeleine were made in the period of the Consulat. In 1800 , Bernard Poyet (1742-1824) wanted to install a Pantheon of the Arts, and Vignon proposed a Palais du Tribunat. ${ }^{9}$ Following the Peace of Amiens (27 March 1802) and the re-establishment of the Catholic religion in France (April 1802), the government opened a competition, and Davy de Chavigné, former Auditeur à la cour des comptes, proposed the transformation of the Madeleine into a Temple of Concord. ${ }^{10}$ None of these plans were acted upon.

Still further proposals for the Madeleine were made shortly after Napoleon's assumption of the imperial throne in 1804. The vist of Pope Pius viI seems to have inspired the idea of completing the Madeleine as a church. Antoine-Laurent-Thomas Vaudoyer (1756-1846) put forward two projects: a church dedicated to Pope Pius vir and based on a strict Greek cross plan (1804), and a parish church in the form of the Pantheon in Rome (1805). ${ }^{11}$ The idea of a parish church was also taken up by François-Jacques Delannoy (1755-1835) who, with the backing of Emmanuel Crétet, Comte de Champmol (1747-1829), Directeur des ponts et chaussées, submitted plans on 14 February $1805 .{ }^{12}$ Although Napoleon initially favoured such ideas, on 21 February 1806 he formally declared his intention, dating back to the summer of 1804, of having the Stock Exchange, the Bank of France, the Court of Commerce, and all their assorted offices established at the Madeleine. ${ }^{13}$ Proposals were submitted by Pierre Vignon and AlexandreThéodore Brongniart (1739-1813), among others, ${ }^{14}$ but objections were raised by the banking community who found the site too far removed from the locus of their activities. Napoleon's premier architecte, Pierre-François-Léonard Fontaine (1762-1853), also opposed the idea, suggesting the site was better suited to a national assembly or an opera house. Plans for the latter were actually

9 Hautecoeur, Histoire, v, 204; Vauthier, "Pierre Vignon," 385.

10 Gruel, La Madeleine, 49-50, and figs. on 51 and 53; Vauthier, "Pierre Vignon," 384; Hauthecoeur, Histoire, v, 204.

11 Hautecoeur, Histoire, v, 204, figs. 126 and 127; Biver, Paris, 234 and 357, no. 12; Kriéger, La Madeleine, 261; B. de Rochebouët, "La Bourse, genèse et construction," in Alexandre-Théodore Brongniart 1739-1813 (Paris, 1986), 135-36, and cat. nos. 143 and $144,180$.

12 Kriéger, La Madeleine, 259-61; Biver, Paris, 234, fig. 66; Rochebouët, Brongniart, 135.

13 Kriéger, La Madeleine, 261-62; Hautecoeur, Histoire, v, 204; Biver, Paris, 232-33; Rochebouët, Brongniart, 131, $135 \mathrm{ff}$.

14 Vauthier, "Pierre Vignon," 384; Hautecoeur, Histoire, v, 204; Rochebouc̈t, Brongniart, 135ff. 
drawn up by Brongniart. ${ }^{15}$ On 31 May 1806 , while this debate was going on, the Minister of the Interior, Jean-Baptiste Nompère De Champagny (1756-1834) made a public request for the submission of designs for a museum of painting and sculpture that would also accommodate various celebrations and the handing out of prizes. ${ }^{16}$

The atmosphere of indecision surrounding the Madeleine finally cleared away in late 1806. At that time, Napoleon was near the pinnacle of his military success; he and his Grand Army had marched victoriously over virtually all of continental Europe. On 2 December, at his camp at Posen, Napoleon decided to commemorate these victories and the heroes of his army by having the Madeleine transformed into a Temple of Glory in their honour. This decision was communicated to the Minister of the Interior, Champagny, in the form of an imperial decree. In accord with the Emperor's wishes, Champagny opened a competition and printed the decree, together with certain stipulations, on 20 December $1806 .{ }^{17}$

The programme, as outlined in Napoleon's decree, specifies that the monument established on the site of the Madeleine be dedicated to the Grand Army and bear on its front the inscription l'Empereur Napoléon aux Soldats de la Grande Armée (Article 1); that marble tablets, inscribed with names of all those who assisted at the Battles of Ulm, Austerlitz, and Jena, be erected in the interior (Article 2); that bas-reliefs of the colonels and marble statues of the marshals be set up around the hall (Article 3); that military trophies from the Grand Army's two campaigns be disposed about the interior (Article 4); that provisions be made for annual commemorative celebrations (Article 5); that part of the existing construction be conserved while keeping the cost to three million francs or less; and that a commission from the Institut des Beaux-Arts report the results of the competition to the Minister of the Interior before March 1807. In an annex, Champagny further stipulated that all designs be in harmony with the portico of the existing structure by Couture (Article $\mathrm{r}$ ); that no perspective drawings be submitted (Article II); that submissions include a ground plan, a front and side elevation, a longitudinal and transverse section, a detail of the order chosen for the new building, and a plan showing the distribution of rainwater (Article III); that the ground plan of Couture's Madeleine be reproduced, and that the colour red be used to identify projected addi-

15 Hautecoeur, Histoire, v, 204: Rochebouët, Brongniart, 135 16 Vauthier, "Pierre Vignon," 385.

17 The text of this decree and the Minister's stipulations are reproduced in their entirety in Gruel, La Madeleine, 65-69; and Krićger, La Madeleine, 262-68. tions (Article IV); that each project be accompanied by an explanatory devis (Article v); and, finally, that the scale of the ground plans, elevations, and sections be one centimetre to the metre, while that of the detail of the chosen order be five centimetres to the metre (Article vi). It was also required that all projects be identified only by a devise, or epigraph, for entries were to be anonymous.

The official results of the 1806-1807 competition for the Madeleine appear to have been reported in a letter written by Champagny and inserted in Le Moniteur of 4 April $1807 . .^{18}$ In this letter, it is recorded that the commission formed from the Beaux-Arts division of the Institut de France had concluded its examination of the 82 submissions on 28 March. ${ }^{19}$ After an expression of His Majesty's official gratitude, the projects accorded the top 21 places are listed by their devise in order of merit. Lastly, the letter invites all competitors to come and retrieve their plans, and those who had obtained distinction are asked to make themselves known.

The competition was clearly an event of considerable contemporary importance. There was a public viewing of the prize-winning entries; as many as 100 projects were submitted; many were subsequently published in pamphlets by their authors; ${ }^{20}$ and nearly every major architectural

18 The extract from Le Moniteur is reproduced in Grucl, $\mathrm{La}$ Madeleine, 69-71.

19 Gruel, La Madeleine, 69, cites a source that gives the number of competitors as 127. Vauthier, "Pierre Vignon," 393 , also gives the number as 82 French and foreign, but adds that the Minister of the Interior only counted those who sent thcir drawings to the office of the Bâtiments civils. Fontaine, Journal, 152, simply says that there were more than 80 projects submitted, but adds that they were all exhibited. A.-L.- T. Vaudoyer, in a letter at the Getty Center for the History of Art and the Humanities (Acc. No. 890()12), reports 92 submissions. Sec. Barry Bergdoll, "I e Panthéon/Saintc-Geneviève," 182, note 15, 297. Vauthier, "Pierre Vignon," 393, claims that all the projects were cxhibited at the Musée Napoléon.

20 See the bibliography in Biver, Paris, 37()-79: the list includes Alexandrc-Jean-Baptiste-(;uy Gisors le Jeune, Jean-Picre-Louis-Iaurent Houel (1735-1813), JacquesGuillaume Lcgrand, Bernard Poyet, and Antoinc-LaurentThomas Vaudoyer, all of whom had their projects published in pamphlet form in 1807. Some of these pamphlets give the devise under which the projects were submitted to the competition. By comparing them with the list in the l.e Moniteur, it is possible to establish that Antoinc-LaurentThomas Vaudoyer placed seventh and Legrand eighth; Poyet's devise is not given in the title of his pamphlet, while Houel's is not listed in the Le Moniteur. Gruel, La Madeleine, 75 , gives the devise of Robit, listed nincteenth in the Le Moniteur. Rochebouët, Brongniart, 141, cites a letter by Brongniart dated 16 March 1807, which she mistakenly connects with a proposal for the Bourse, but which repeats the requirements for the Temple of (;lory competition, and gives as devise "vires acquirit eundo," listcd sixth in the Le Moniteur. 
figure in the capital participated. That the programme of the competition was so explicit in calling for solutions in the classical style, that many of the respondents later explicated the rationale for their proposals in a pamphlet, and, as we shall see, that Napoleon himself commented on the result, should make the competition even more significant to the historian. It represents an extraordinary test of theory against practice, and an opportunity to examine a wide range of designers' approaches to one imaginary building, a Temple of Glory, the functions of which were described in the programme. However, the secondary literature on the competition is confusing, and only a small number of the entries or entrants can as yet be traced with certainty. The difficulties of reconstructing the event, locating surviving proposals, and establishing authorship are complicated by the required anonymity of submissions. Some of the importance of the project bound in the CCA album therefore derives from the fact that the authors, Baltard and Rondelet, chose to identify themselves, enunciate their proposals, and bind and retain at least the principal part of their submission.

Of those artists who attained distinction in the competition, the names of the first four are known from several contemporary sources. ClaudeEtienne de Beaumont (1757-1811) was awarded the first prize; Pierre Vignon, Alexandre-JeanBaptiste-Guy Gisors le Jeune, and Antoinc-Marie Peyre (1770-1843) were granted honourable mentions in that order. ${ }^{21}$ Secondary sources give the names, but not the placements, of several other participants, among them Bernard Poyet, Charles-Pierre Normand (1765-1840), FrançoisJacques Delannoy, Antoine-Laurent-Thomas Vaudoyer, and Alexandre-Théodore Brongniart. $^{22}$

That the contents of the CCA's albuin were produced in connection with Napoleon's competition of 1806-1807 cannot be doubted. The fragmentary pamphlet (Figs. 166 and I67), the manuscript devis (Fig. 168), and the cover of the album itself (Fig. 163) all reproduce the title of the competition as published in Napoleon's decree. The pro-

21 Herc it suffices to cite lontaine, Journal, $152 \mathrm{ff}$. Some of the drawings submitted by Bcaumont and Vignon, now in the Archives Nationales, are also reproduced in liontaine. Pcyrc reproduced his project in his Projet d'architecture (Paris, 1812), pls. 1-4.

22 Hallccoeur, Histoire, v, 207 and 297: Bircr, Paris, 245; Rochebouät, Brongniart, 139; Fontaine, Journal, 155 , 11. 112. Some of the projects were apparently reproduced in C.-P. Landon, Annales du Musée, 2nd ed. (Paris, 18.33), and it is from this source that Gruel, L.a Madeleine, 75-76, reproduces the project of Robit, and Hautecoeur that of Normand, fig. 197, 297. grammatic requirements of this decree and of Champagny's annex are met point for point by the drawings (Figs. 169 to 173). In the introductory address (Fig. 164) and in the notes on drawing number five (Fig. 173) it is stated that the enclosed project was viewed by the Commission from the Institut, the notes on drawing number five specifying the date of 18 March for this viewing. Most importantly, the authors state in the introductory address (Fig. 164) that their project, submitted under the devise of "Mars et Minerve," obtained fifth place. A project with the devise "Mars et Minerve" is indeed listed fifth by Champagny in Le Moniteur of 4 April 1807.

While the contents of the cca's album can easily be connected with Napoleon's Temple of Glory competition, the precise nature of that connection is not so readily apparent. The presence of the signatures of Baltard and Rondelet on a project that was supposed to be anonymous, the statement in the introductory address and in the notes on drawing number five that the project had already been viewed by the official commission and awarded fifth place, the fact that the introductory address is not addressed to the members of the commission but to the Emperor, and the presence of an alternate project on the bottom of drawing number five (expressly referred to in the notes as an addition), all indicate that the ccA's record of Baltard and Rondelet's competition entry is not identical with their original submission.

There are also questions concerning the relationship between those contents of the album that are bound in, and those that are not. The printed pamphlet (Figs. 166 and 167) and the manuscript devis (Fig. 168) definitely belong together. They have the same devise - a quotation from Herodotus - and give the same total cost estimate of 2,940,684 francs 42 centimes. However, this estimate, the devise from Herodotus, as well as the proposed design (identified as figure three on page three of the pamphlet ${ }^{23}$ ) do not correspond to either of the two projects bound into the album.

Some of the problems posed by the contents of the cca's album are resolved by an account of cvents that occurred after the official close of the 1806-1807 compctition. The question of who would be given the commission to build Napoleon's Temple of Glory was not settled by the jury. Apparently no one was happy with the selection of Charles-Etienne de Beaumont, especially not the other three top prize winners. ${ }^{24}$ Napoleon, then encamped at Finkenstein, was apprised of

\footnotetext{
23 On page three of the printed pamphlet, figurc one reproduces Contant's last-known plan for the Madeleinc, and figure two reproduces the plan of Couture.

24 Fontainc, Journal, 154-58.
} 
the situation in early April and instructed Fontaine, his premier architecte, to meet with the prize winners at Champagny's home, and send him a report. Fontaine's report, ${ }^{25}$ in which each of the four winning projects, especially that of ClaudeEtienne de Beaumont, came in for heavy criticism, was sent on 14 May, but did not arrive at Finkenstein until 3 June. Meanwhile, on 29 May, with only the four prize-winning projects in hand, and growing impatient, Napoleon decided to award the commission to Pierre Vignon, saying that of the four, his project best represented the Emperor's intention to build a temple in the Greek manner:

[C'est] le seul qui remplit mon intention.... C'est un temple que j'avais demandé et non une église. Que pouvait-on faire dans le genre des églises qui fut dans le cas de lutter avec Sainte-Geneviève, même avec NotreDame et surtout avec Saint-Pierre de Rome? ${ }^{26}$

This decision was conveyed to Vignon by the Minister of the Interior on 9 June. However, things did not end there, for the choice of Pierre Vignon also created a public and professional stir. Napoleon became nervous and considered appointing another architect, with Vignon as contrôleur. The Minister of the Interior suggested Jean-Baptiste Rondelet, then architect of the Panthéon, but Vignon resisted. Eventually, as we know today, Vignon's proposal succeeded, although his project (which was re-dedicated in 1813 , during construction, as a church) continued to be surrounded by controversy until his death in $1828 .{ }^{27}$

There was, therefore, a period of at least two months - 4 April until 9 June 1807-when the final decision regarding Napoleon's commission remained very much in doubt. It may have been during this time that Louis-Pierre Baltard and Jean-Baptiste Rondelet decided to send their fifth-place competition entry - now bound with a variant form of the design and an introductory address - to Napoleon, pleading for reconsideration. On the other hand, from the wording of the address, it may have been sent only after Napoleon's declaration in favour of Pierre Vi-

25 Reproduced in Fontaine, Journal, 154-58.

26 Letter, now in the Archives Nationales (F 13, 1147), from Napoleon to Champagny, 30 May 1807. Quoted in Bergdoll, "Le Panthéon/Sainte-Geneviève," 183. Further on in the letter, Napoleon defines what he means by a temple: “. . par temple, j'ai entendu un monument tel qu'il y en avait à Athénes ...." Sce Kriéger, La Madeleine, 271.

27 In early 1816, after the restoration of the Monarchy, new plans were requested from other architects, including one by Baltard. See Vauthier, "Pierre Vignon," 405, and Hautecoeur, Histoire, vi, 17. gnon. ${ }^{28}$ From current evidence, it is impossible to say whether Napoleon ever saw it.

Baltard was reported to have used the anonymity of the competition to submit as many as four different proposals to the jury. ${ }^{29}$ Because these initial entries were anonymous, it is now difficult to establish whether the project represented by the fragmentary printed pamphlet and the manuscript devis was authored by Baltard, in addition to his fifth-place entry. However, the quotation from Herodotus, by which this project is identified, is not listed among the 21 prize winners, and it seems unlikely that Baltard would have gone to the trouble of having an unplaced project printed anonymously in pamphlet form, while at the same time pleading with the Emperor for his fifth-place entry under his own name. A more probable explanation would be that the project bearing the quotation from Herodotus is the entry of some other, as-yet-unknown contestant, one who, like other disgruntled contestants, pleaded his case in the public form of a printed publication. How the pamphlet and the manuscript devis came to be placed with the cCA's album remains unclear. Perhaps they, together with the bound contents of the album, formed part of a larger group of documents related to some later imperial review of the competition. It is also possible that, at some point in their provenance, the relationship between all the present contents of the album and the Temple of Glory competition was recognized by a collector, whether Hippolyte Destailleur or someone else, and simply put together.

The initial anonymity of competition entries further allows us to ask whether the CCA's fifthplace entry was genuinely co-authored from the beginning by Rondelet. Both the introductory address and the notes on drawing number five appear to have been written by him, but the drawings themselves are undoubtedly the work of Baltard ${ }^{30}$ Perhaps, as part of his effort to have the

28 The wording of the introductory address, folio 3r, may indicate that Baltard and Rondelet were aware of Napoleon's desire for a building having the form of a temple rather than that of a church. This desire is not made explicit in the official programme, but was certainly expressed in the letter of 30 May 1807, in which Napoleon declared to Champagny his decision as to the winner of the competition.

29 In a letter of A.-L.-T. Vaudoyer to Le Bas at the Getty Center for the History of Art and Humanities, cited in Bergdoll, "Le Panthéon/Sainte-Geneviève," 182. See note 19.

30 The handwriting of the introductory address and of the notes on drawing number five in the CcA's album does not match any samples of Baltard's known to the author, but it does resemble that of Rondelet. See E.-L.-G. Charvet, Lyon artistique. Architectes: Notices biographiques et bibliographiques (Lyon, 1899), 343. On the other hand, the meticulous draw- 
Emperor reconsider his suitability for the Temple of Glory commission, Baltard simply enlisted Rondelet's name and reputation as an experienced builder and an officer in Napoleon's architectural bureaucracy. ${ }^{31}$ Given Baltard's ambitions, his lack of position, and meagre history of commissions, his enlistment of Rondelet would have made good sense. The two men were certainly closely acquainted. Baltard had worked many times in Rondelet's native city of Lyon. Both held professorships at the Ecole des Beaux-Arts in Paris. Baltard, together with Antoine-Laurent-Thomas Vaudoyer, delivered the eulogy at Rondelet's funeral in 1829. Baltard also took over from Rondelet as architect of Sainte-Geneviève in 1813. ${ }^{32}$

The album in the cca composed by Louis-Pierre Baltard and Jean-Baptiste Rondelet suggests a number of avenues for future research. Scholars may wish to examine the drawings in the context of Baltard's early oeuvre. Baltard is well remembered for his activities as a teacher, but little is recorded of his architectural practice before 1815 , the date of his first known commission, the chapel

ing style, clearly Baltard's, is very close to that exhibited by another drawing signed and inscribed, and executed in 1797 by Baltard, also in the CCA, which originally formed part of his entry in the competition for a Triumphal Arch at the (Château-Trompête, Bordeaux (DR1984:1461). See Alan Salz and Beverly Schreiber Jacoby, French Master Drawings (New York, 16 May-9 June 1984), no. 1, fig. 42, and an unpublished report by Myra Nan Rosenfeld, 19 June 1984, cc.A Prints and Drawings Research Files. For Baltard's drawing style at the time of the competition, see Puylaroque, "Louis-Pierre Baltard," 331-39. The author has also been able to see the drawings in the cca's album juxtaposed with two groups of drawings by Baltard for the Church of Sainte-Geneviève. These two groups of drawings, also in the CCA's collection (DR 1964:004:01-03 and DR 1984:1587-1591), were exhibited in the same exhibition as the Baltard/Rondelet album. See Bergdoll, "Le Pantheon/Sainte-Geneviève," 192, note 43, and 193, for the ill. of DR1964:004:003: 197-200, and 199 for the ill. of DR 1984: 1588 and 1589, and note 67, 297. The latter drawings have been discussed by Rosenfeld in an unpublished report, 21 June 1984, ccs Prints and Drawings Research Files.

31 Rondelet was highly regarded for his knowledge of technical matters pertaining to construction, and he had written a widely-used book on the subject. He had also written a report on the stability of Couture's portico of the Madeleine in 1786. See Soufflot et son temps, 157.

32 Puylaroque, "Louis-Pierre Baltard," 331 of the Prison of Sainte-Pélagie in Paris. The drawings in the album provide evidence that Baltard's early projects executed before 1815 were of such a high calibre that he merited placement, alongside such well-reputed and experienced architects as Bernard Poyet, Antoine-Laurent-Thomas Vaudoyer, and Alexandre-Théodore Brongniart, in the most important competition of the time. But, for an architect starting his career in the first days of the Revolution, 20 years may not have been an uncommon length of time to wait for a first commission.

The introductory address (Figs. 164 and 165), with its reference to a specific classical model, the Augustan Temple of Mars Ultor in Rome, and the various other allusions to ancient Roman architecture contained in the drawings, are also almost equally provocative. This choice of prototype was perhaps a mistaken attempt to flatter an emperor looking for Greek, not Roman, exemplars. Nevertheless, using the drawings (which document an elaborate ornamental scheme articulated on a simple building plan) as evidence, the very notions of simplicity or grandeur, to which the authors' introductory address refers, can be tested against the spatial and visual ideas they found to express these qualities. There is, furthermore, a clear relationship between this proposal, the present-day church (upon which Rondelet himself later worked extensively ${ }^{33}$ ), and earlier attempts to recast the Madeleine in a more classical form. Most important, the discovery of this astonishingly refined and beautiful set of drawings should inspire the research needed to clarify the history of a competition that comes at the high point of Napoleon's infatuation with the Greek past, of his identification with Alexander, and of his dreams of making Paris an imperial city - a moment that produced a multitude of notions for civic projects and a torrent of architectural ideas, some suppressed and only to be realized half a generation later.

33 The Getty Center for the History of Art and Humanities has a group of drawings by Rondelet for the Madeleine. These drawings, which concern the structure of Vignon's design, are of a technical nature. They are part of accession number 840018 , entered under Jacques-Germain Soufflot and Jean-Baptiste Rondelet.

Centre Canadien d'Architecture/ Canadian Centre for Architecture 1920, rue Baile

Montréal, Québec H3H $2 S 6$ 


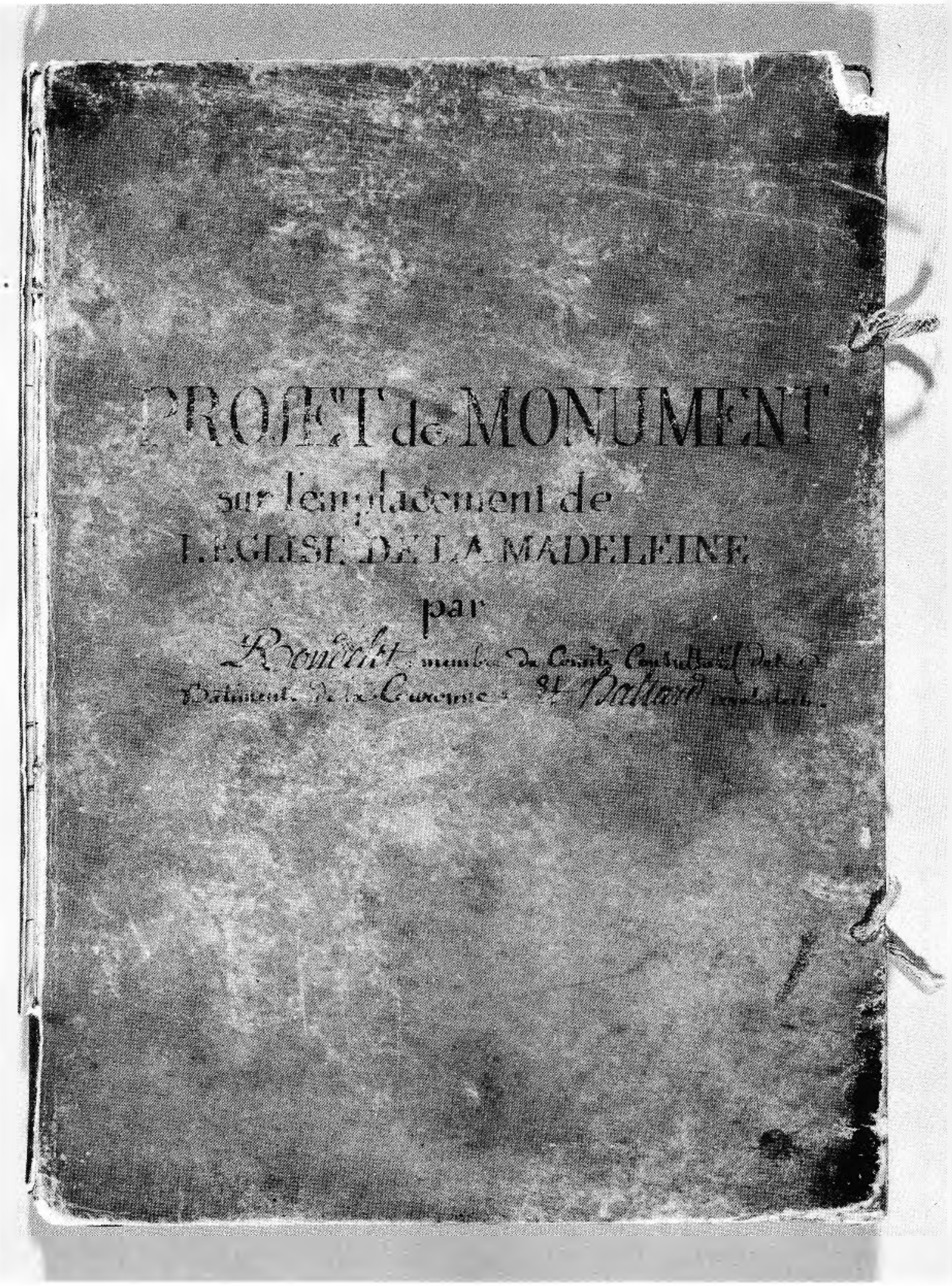

Figure 163. Louis-Pierre Baltard, France, Paris 1764-Lyon 1846, and Jean-Baptiste Rondelet, France, Lyon 1743-Paris 1829, Album Cover, green parchment inscribed with pen and black ink, $1807,40.3 \times 29.6 \mathrm{~cm}$. DR 1988:0270, Collection Centre Canadien d'Architecture/Canadian Centre for Architecture, Montréal. 

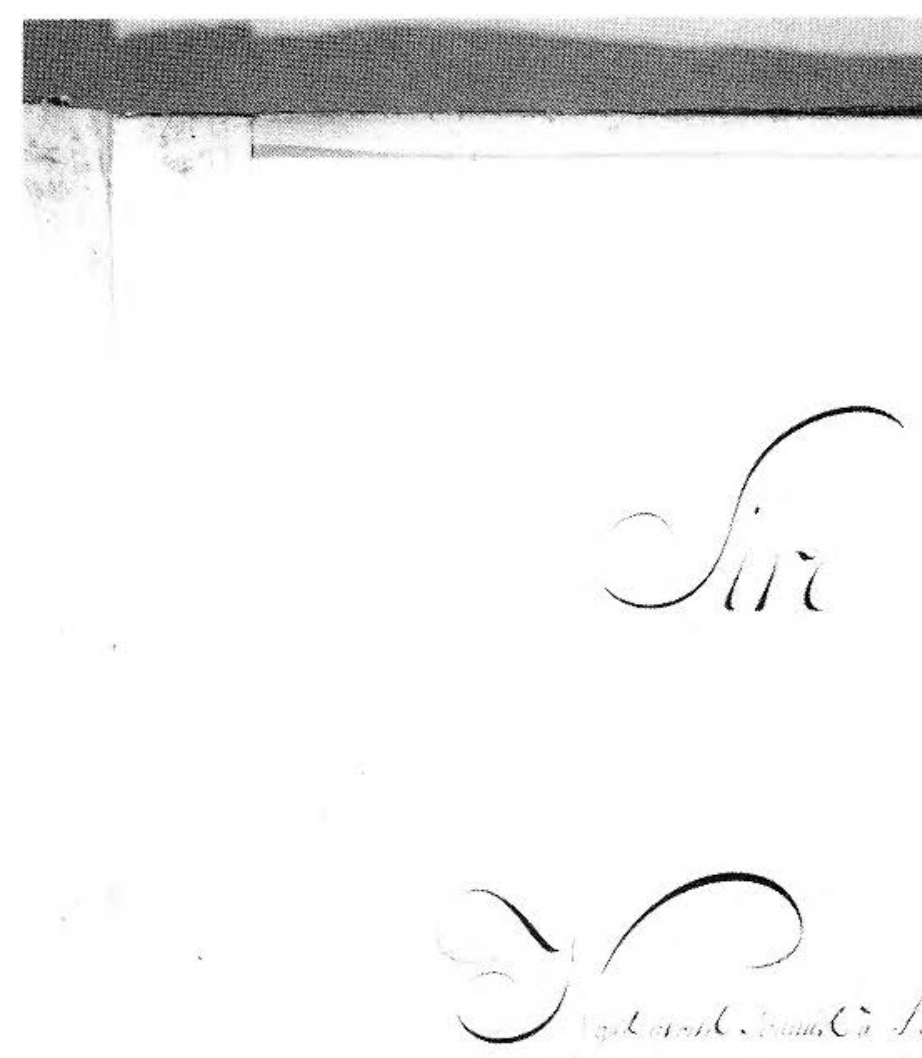

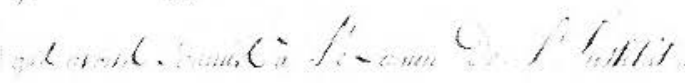

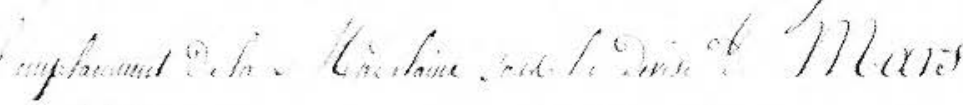

1

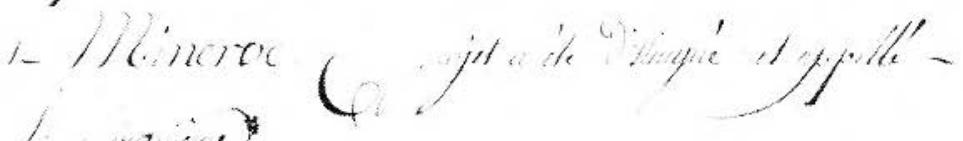

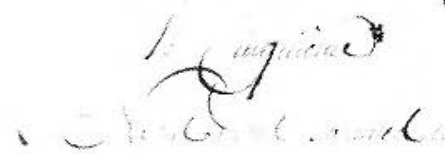

Whe pe

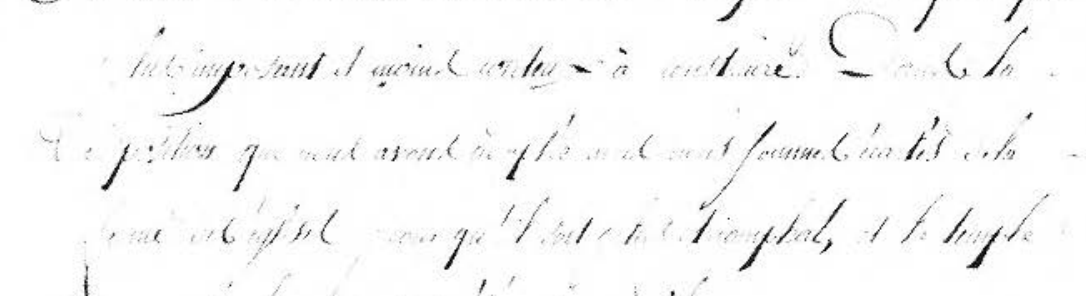

$-1 / 1 / 1$

(1,

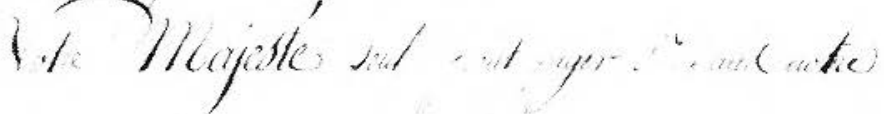

Figure 164. Louis-Picrre Baltard, France, Paris 1764-Lyon 1846, and Jean-Baptiste Rondelet, France, Lyon 1743-Paris 1829, Introductory Address, Page One, pen and black ink, 1807, 36.5 × 28.7 cm. DR1988:0270 folio 3, Collection Centre Canadien d'Architecture/Canadian Centre for Architecture, Montréal. 


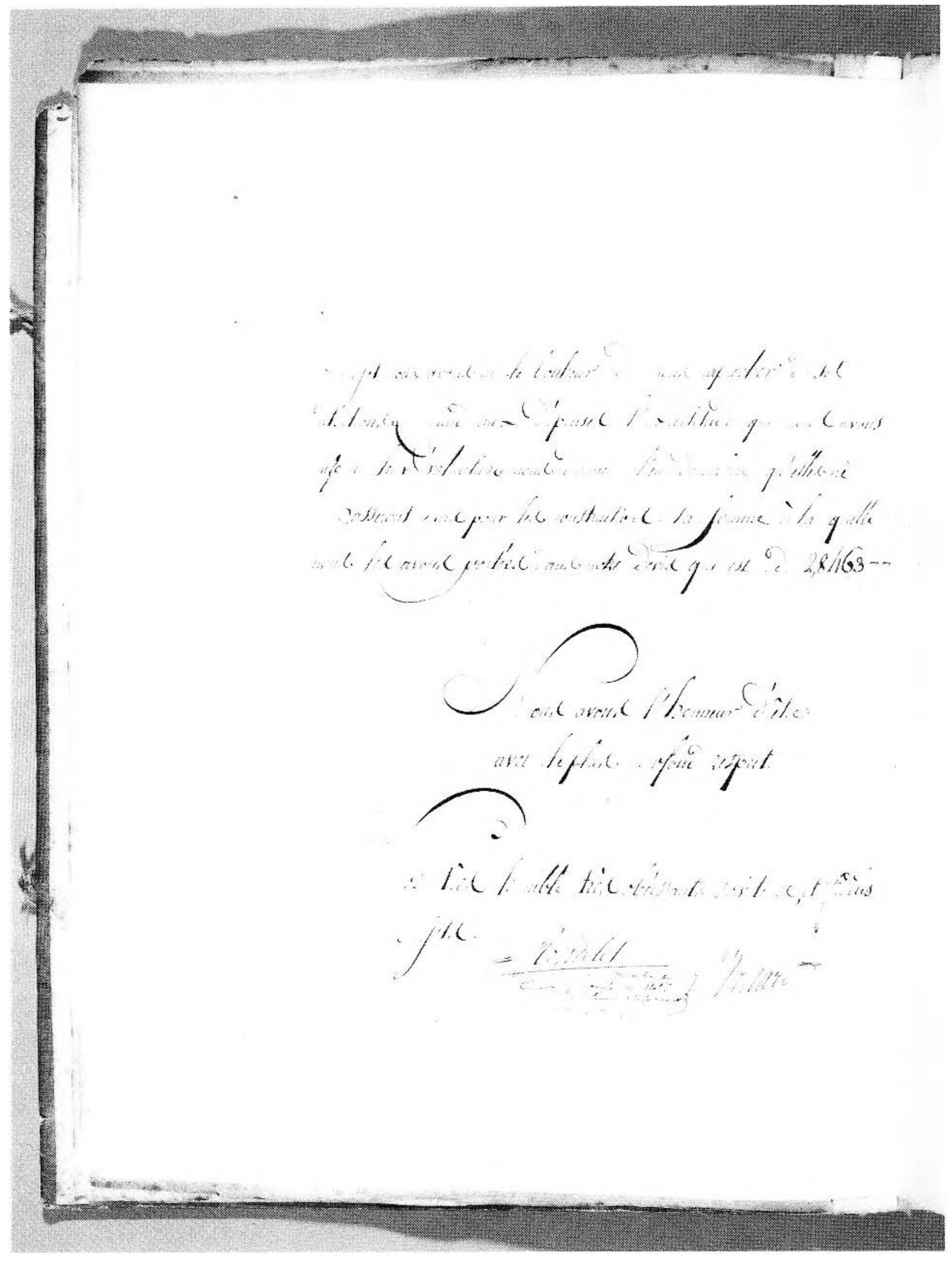

Figurf 165. Louis-Pierre Baltard, France, Paris 1764-1yon 1846, and Jean-Baptiste Rondelet. France, Lyon 1743-Paris 1829. Introductory Address, Page Tiuo, pen and black ink, 1807, 36.5 ×28.7 cm. DR 1988:027(0) Folio 3 verso, Collection Centre Canadien d'Architecture Canadian Centre for Architecture, Montréal. 


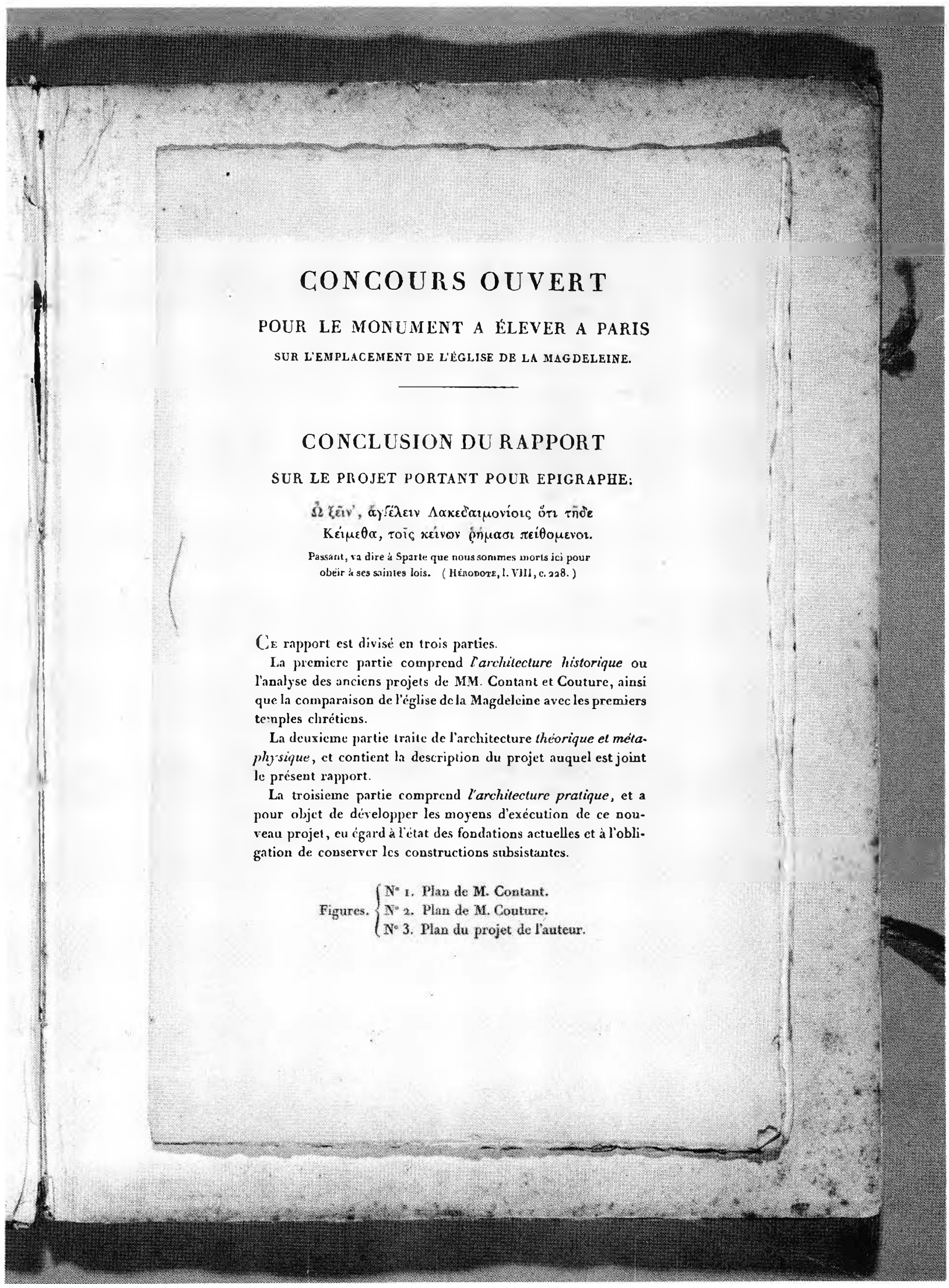

Figure 166. Anonymous, Pamphlet, Page One, engraving, 1807, 35.0 $\times 22.4 \mathrm{~cm}$. Collection Centre Canadien d'Architecture/Canadian Centre for Architecture, Montréal. 


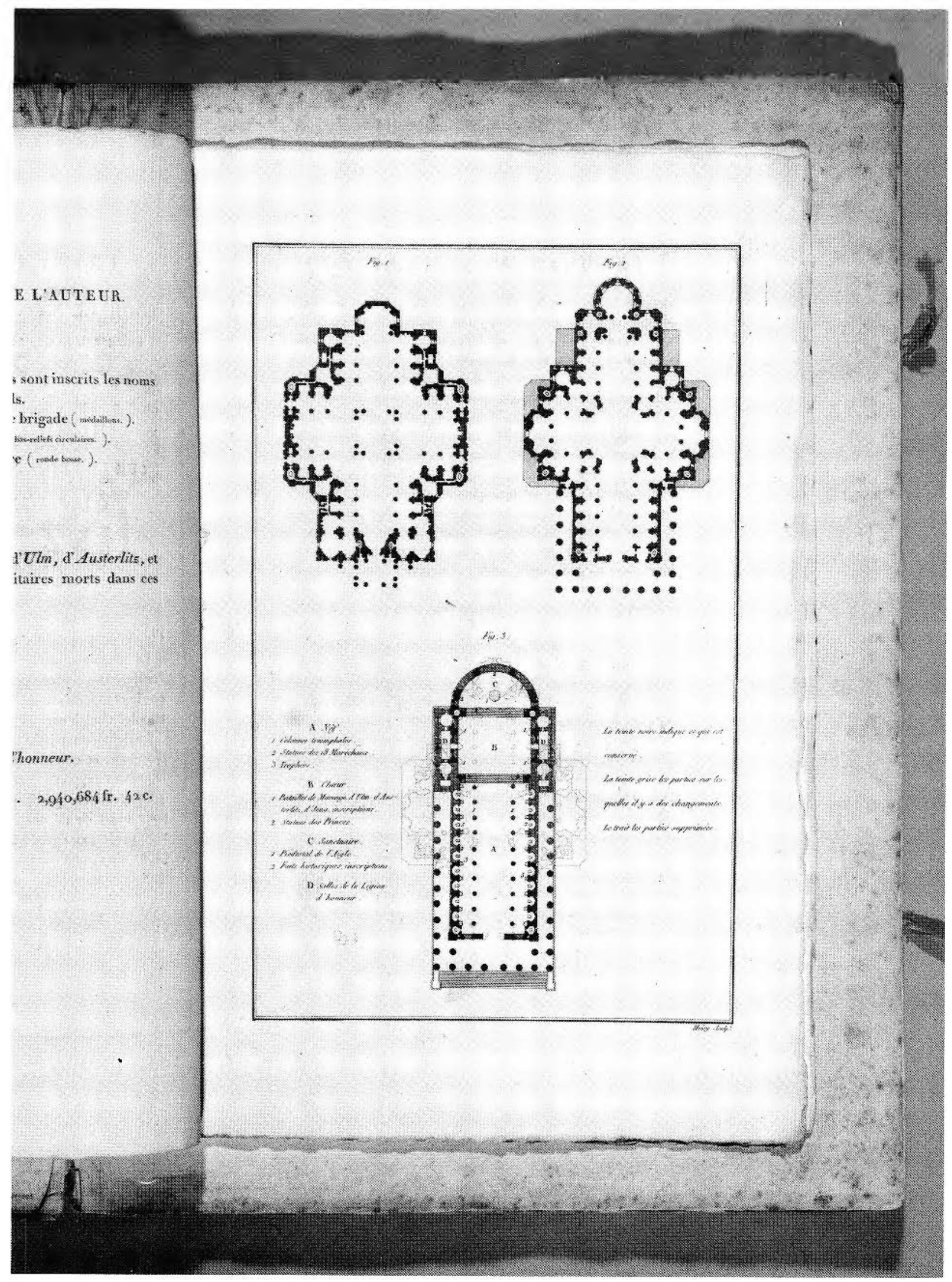

Figure 167. Anonymous, Pamphlet, Page Three, engraving, 1807, $35.0 \times 22.4 \mathrm{~cm}$. Collection Centre Canadien d'Architecture/Canadian Centre for Architecturc, Montréal. 


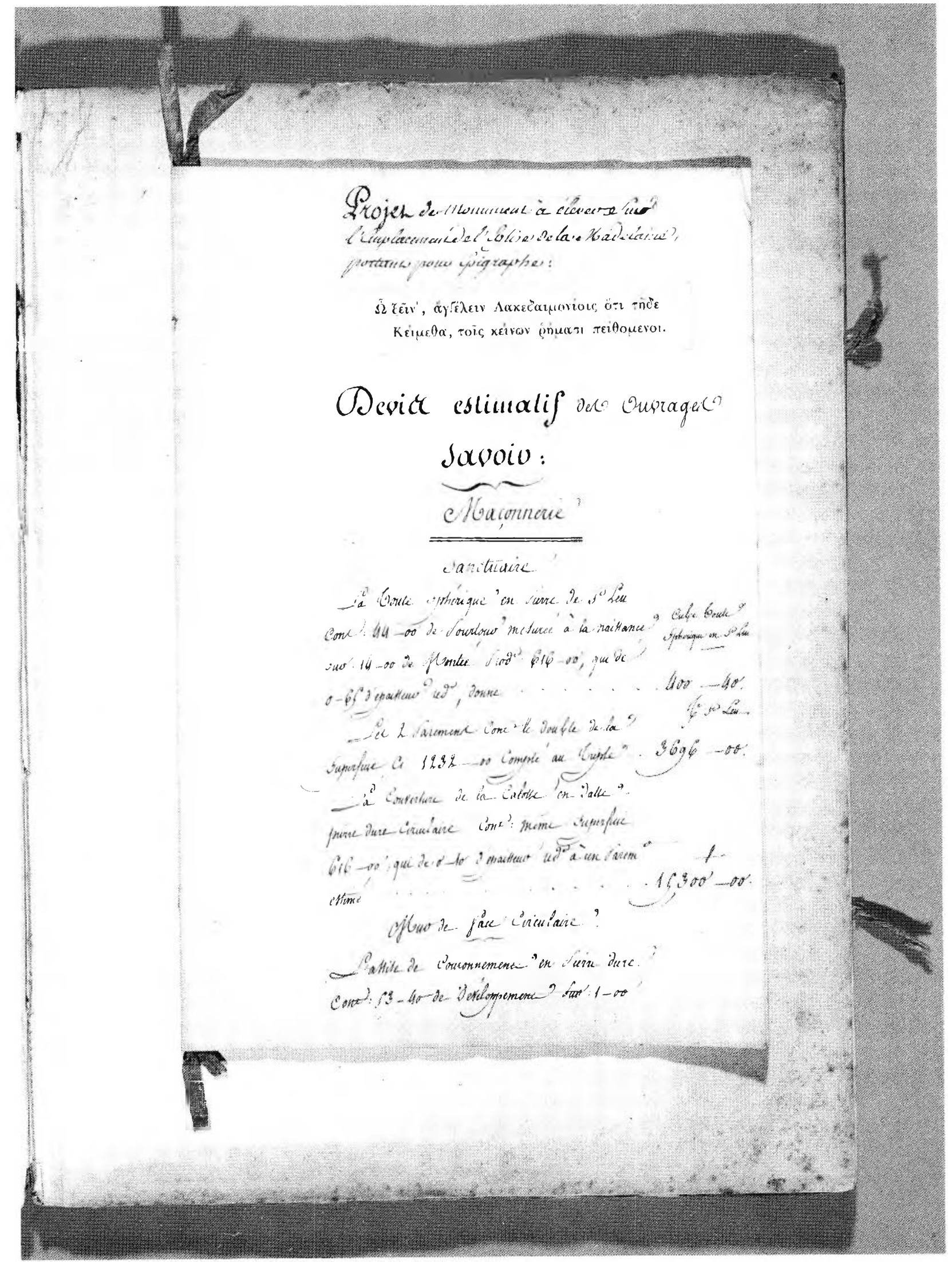

Fisire 168 . Anomymous, Conering Page of a Manuscript Estimate of Costs, pen and brown ink, $1807,31.6 \times 21.0$ cin. (iollection Centre Canadien d'Architecture/Canadian Centre for Architecture, Montréal. 


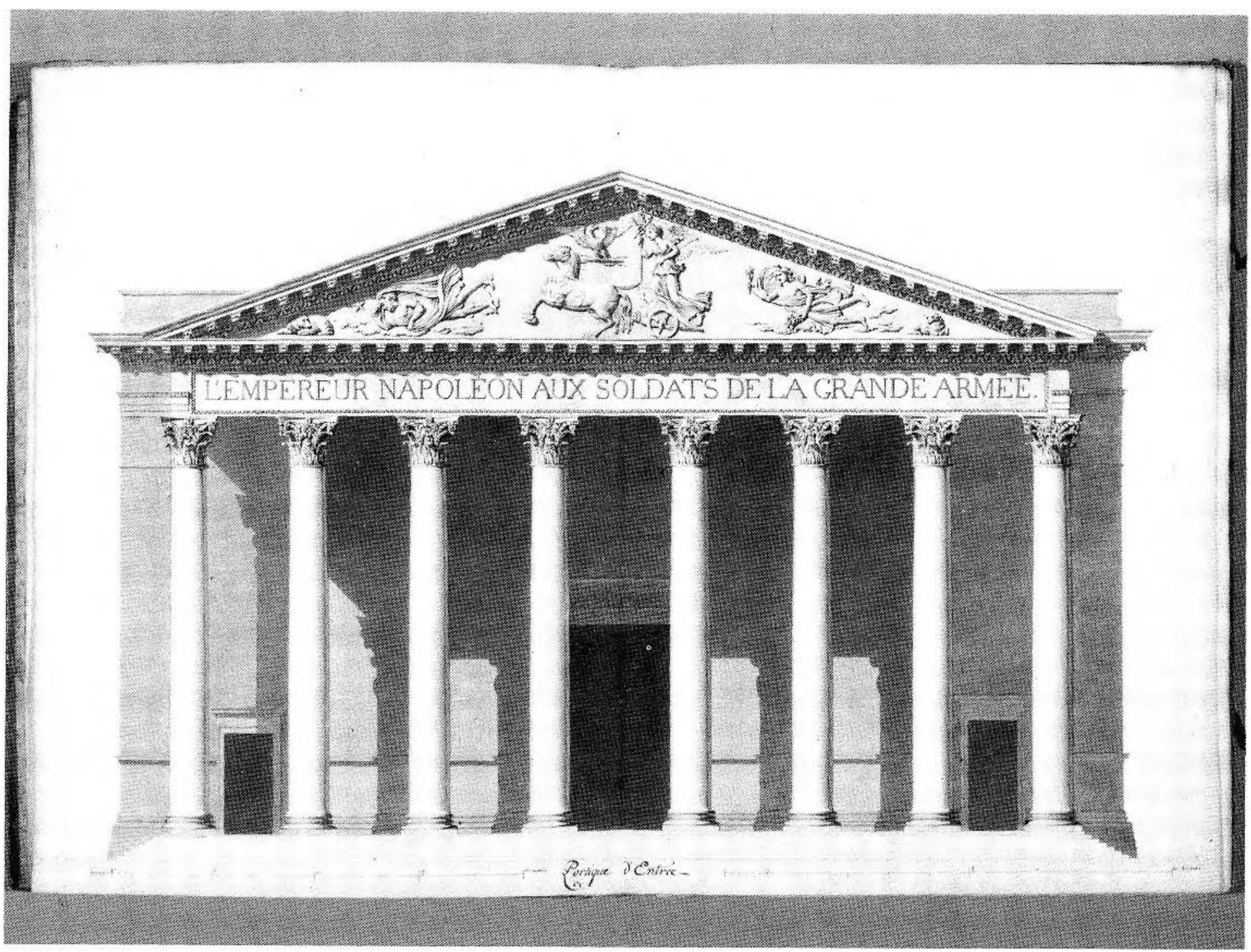

Fisure 169. Iouis-Pierre Baltard, France, Paris 1764-Lyon 1846, and Jean-Baptiste Ronclelet, France, Lyon 1743-Paris 1829, Elevation of the Principal Fasade for the Temple of (Flory, pen and black ink with black, yellow, and pink wash over graphite (inscribed title in brown ink), 1807, 39.8 $57.7 \mathrm{~cm}$. DR 1988:(0270:001, (iollection Centre Canadien d'Architecture/Canadian Centre for Architecture, Montréal. 


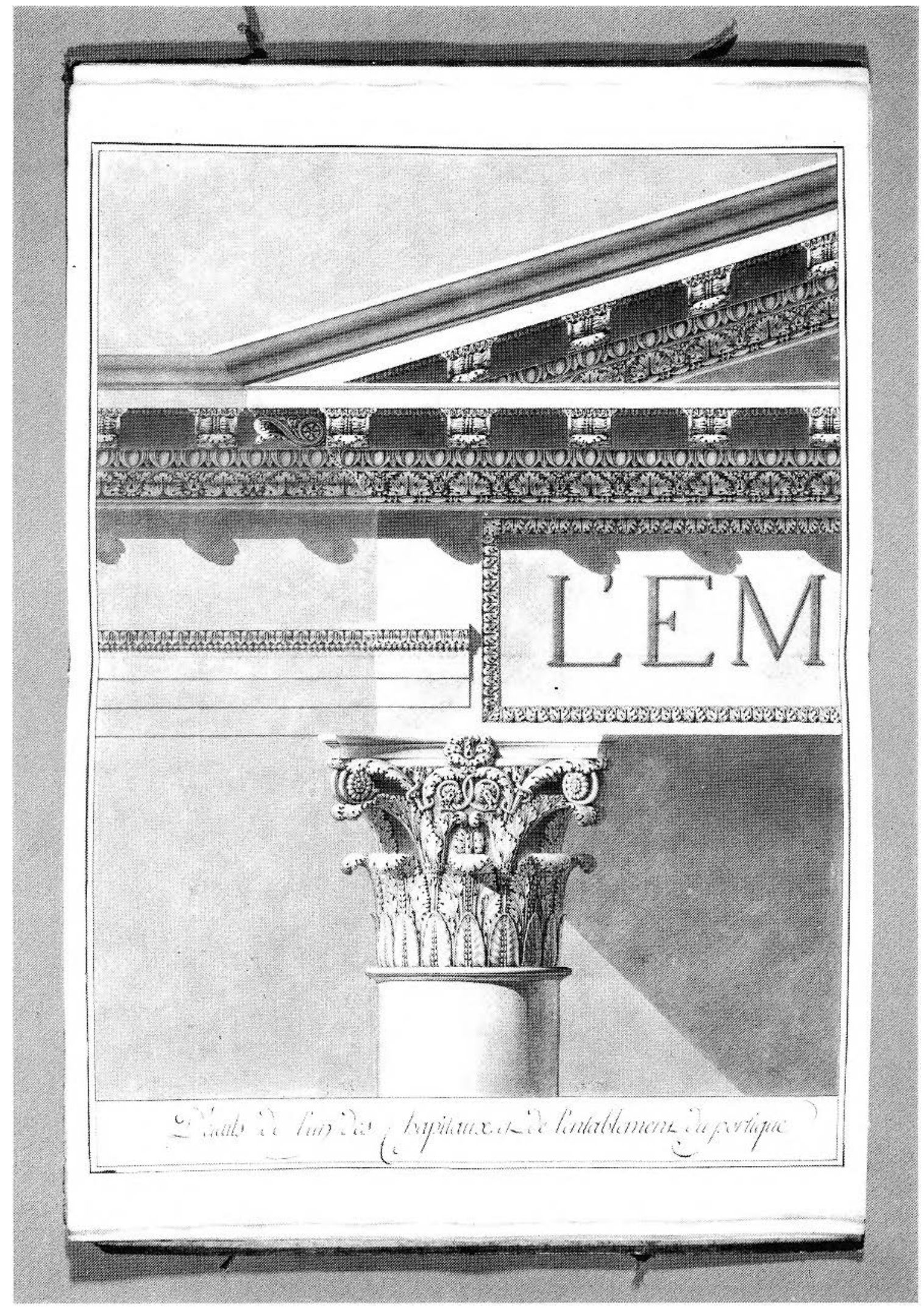

Fistre: 170. Louis-Pierre Baltard, France, Paris 1764-1yon 1846, and Jcan-Baptiste Rondelet, France, lyon 1743-Paris 1829, Detail of Ornament from the Principal Façade for the Temple of Glory, pen and black ink with black and ycllow wash over graphite (inscribed title in brown ink), 18(07, 37.7 ×51.7 (m (secondary support). 1)R 1988:0270:002. Collection Cintre Canadien d'Architecturc/Canadian Centre for Architecture, Montréal. 


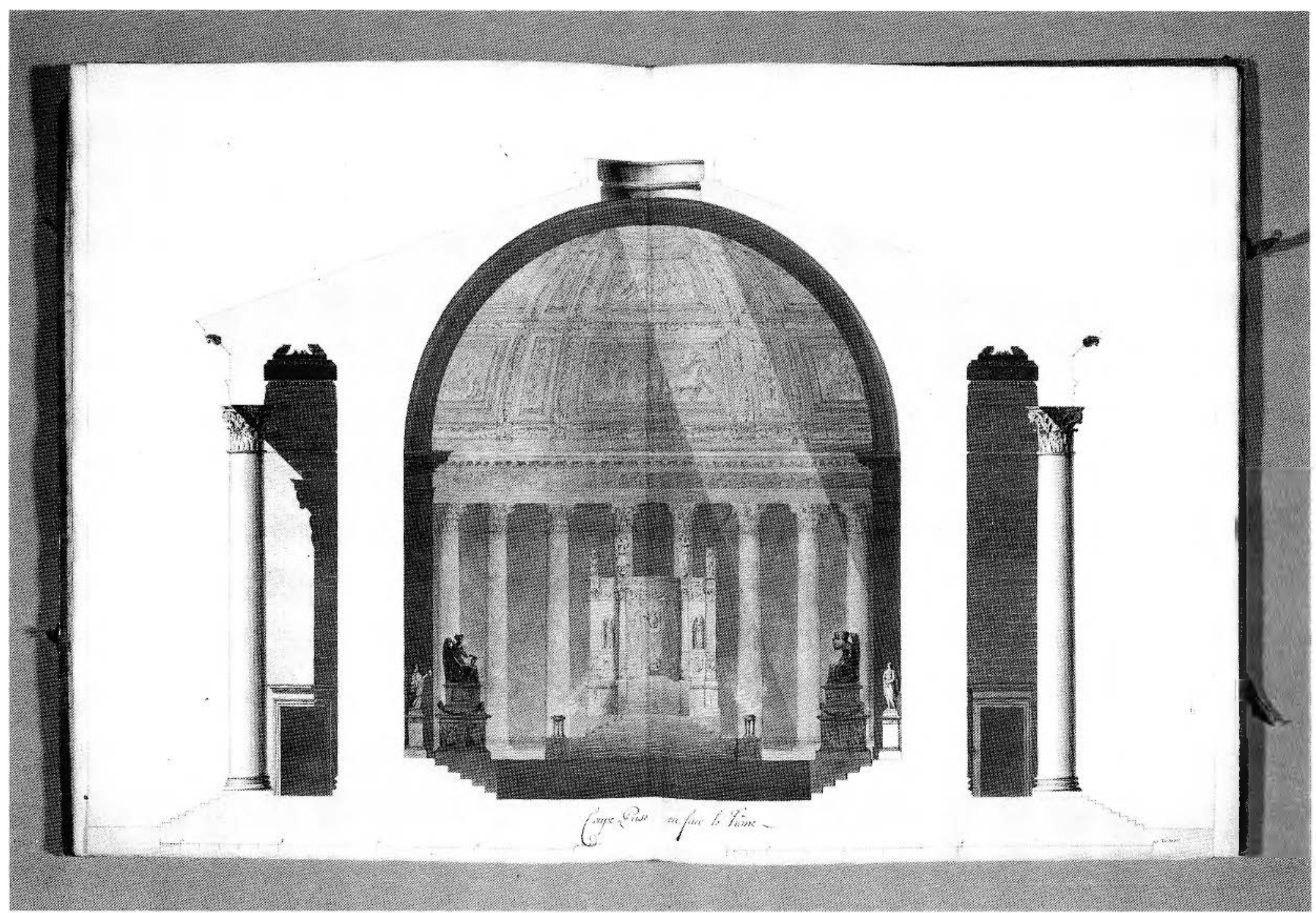

Figtre 171. Louis-Pierre Baltard. France, Paris 1761-Lyon 1846, and Jean-Baptiste Rondelet, France, Lyon 1743-Paris 1829, Cross-section for a Temple of Glory, pen and black ink with black, yellow, pink and blue wash and watercolour over graphite (inscribed title in brown ink), 1807.40.0 ×57.5 cm. DR 1988:0270:003, Collection Centre Canadien d'Architecture/Canadian Centre for Architccture, Montréal. 


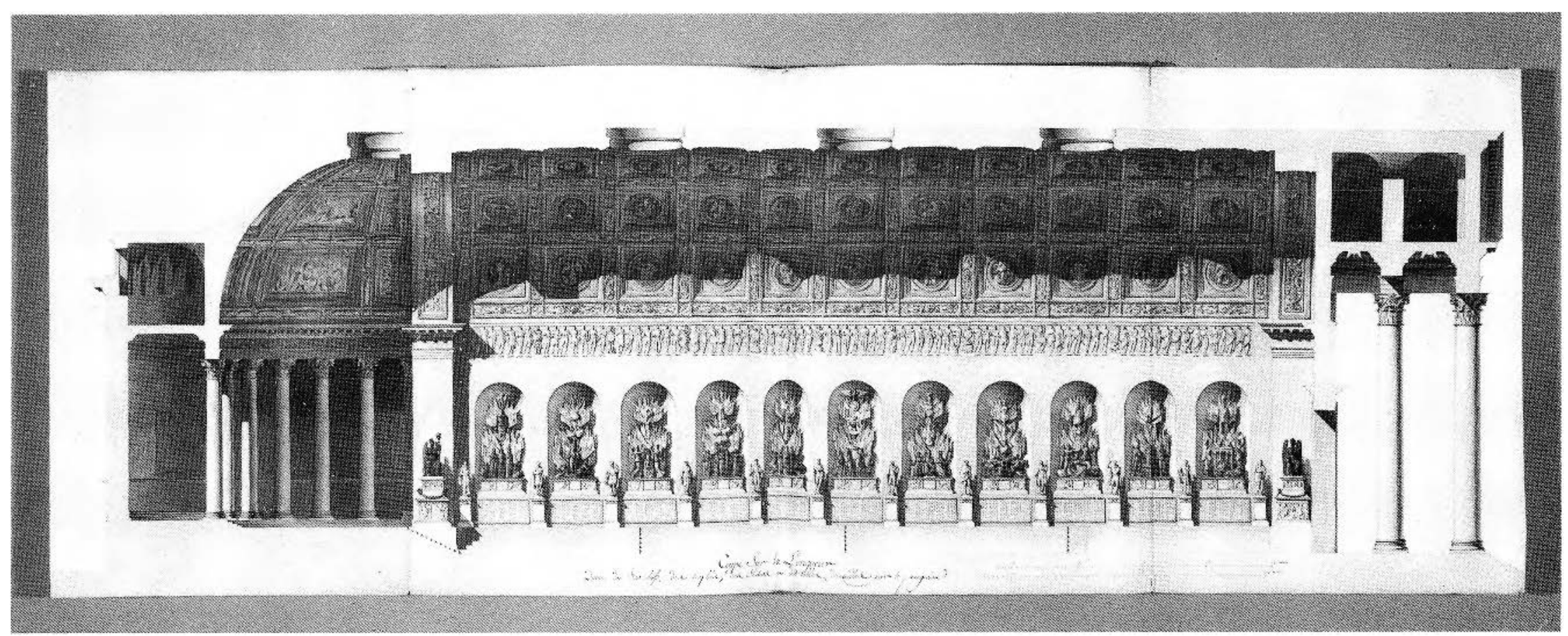

Figure 172. Louis-Pierre Baltard, France, Paris 1764-Lyon 1846, and Jean-Baptistc Rondelet, France, I.yon 1743-Paris 1829, Longitudinal Section for a Temple of Glory, pen and black ink with black, yellow, pink, blue and green wash and watercolour over graphite (inscribed titlc in brown ink), 1807,40.0 × 113.6 cm. 1) R 1988:0270:004, Collec- 


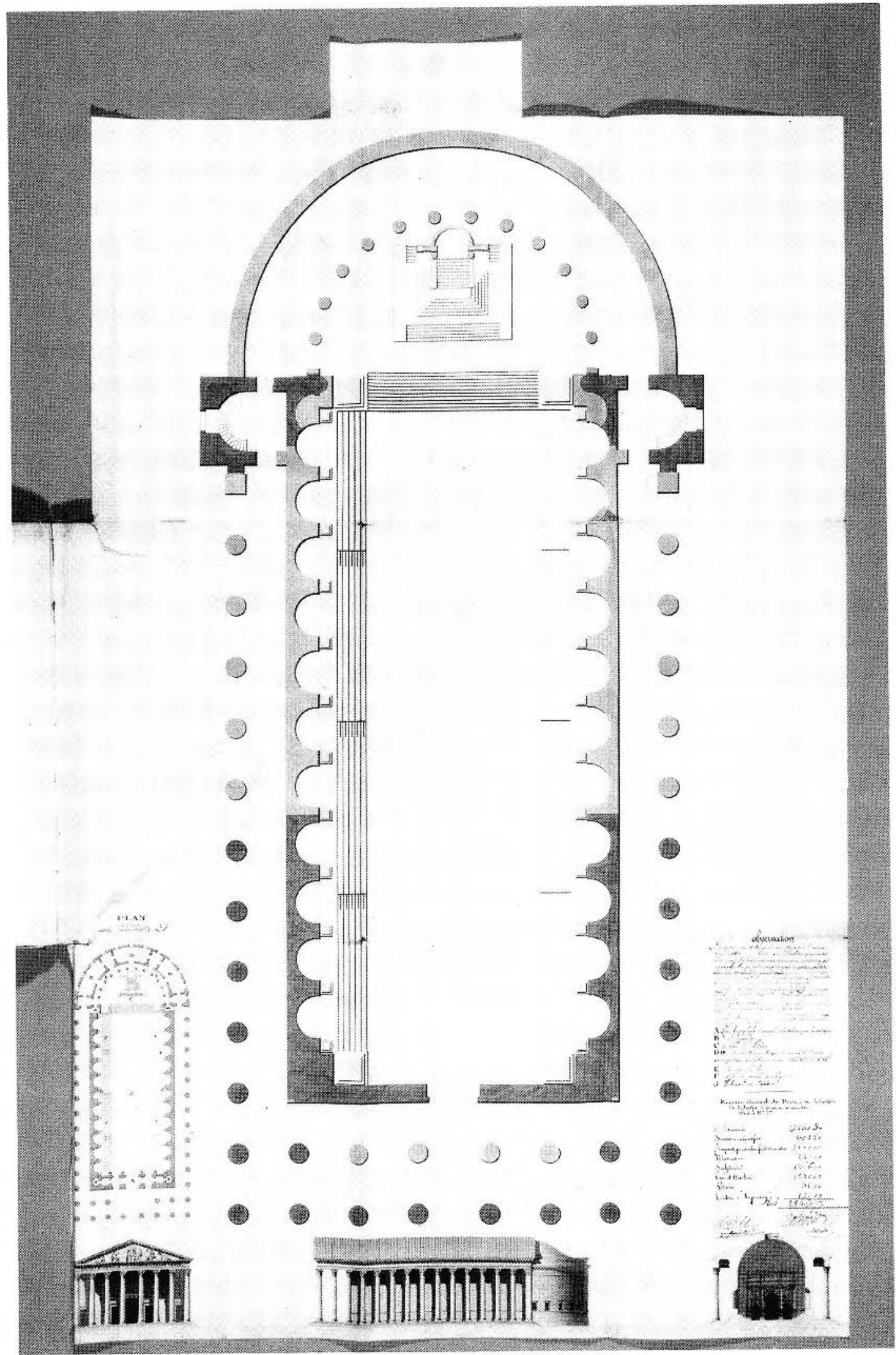

Figurf 173. Louis-Pierre Baltard, France, Paris 1764-Lyon 1846, and Jean-Baptiste Rondelet, France, Lyon 1743-Paris 1829, Plan and Alternate Proposal for the Temple of Glory, pen and black ink with black, yellow, and pink wash over graphite (inscribed title, etc. in brown ink), 1807, $116.6 \times 75.3 \mathrm{~cm}$ (irregular). DR 1988:0270:005, Collection Centre Canadien d'Architecture/Canadian Centre for Architecture, Montréal. 